\title{
Thermographic images from healthy knees between dogs with long and short hair
}

\author{
Roberto Harutomi Corrêa Nomura ${ }^{1}$ Itallo Barros de Freitas $^{1 *} \odot$ Rogério Luizari Guedes $^{1}$ \\ Frederico Fernandes Araújo ${ }^{1}$ Amanda Cristina Duarte Neves Mafra ${ }^{2}$ \\ José Fernando Ibañez $^{3}$ Peterson Triches Dornbusch ${ }^{3}$
}

${ }^{1}$ Programa de Pós-graduação em Ciências Veterinárias (PPGCV), Universidade Federal do Paraná (UFPR), 80035-050 Curitiba, PR, Brasil. E-mail:itallobf@gmail.com. ${ }^{*}$ Corresponding author.

${ }^{2}$ Profissional Autônoma, Joinville, SC, Brasil.

${ }^{3}$ Departamento de Medicina Veterinária da Universidade Federal do Paraná (UFPR), Curitiba, PR, Brasil.

ABSTRACT: The aim of this study was to investigate the influence of fur length in the evaluation of knees temperature in healthy dogs, using infrared thermography. This is a non-invasive diagnosis that is able to assess the microcirculation of the internal skin. Changes in temperature reflect from inflammatory reactions and vascular infarction to neurological disorders. Knees of 30 healthy dogs were analyzed, with up to 11 pounds of weight, screened by clinical examination and radiographic examination. Group A, consisting of 13 dogs with short fur, with 26 knees evaluated in total. Group B included animals with long fur, consisting of 17 animals, with 29 knees evaluated in total. The average temperatures of the cranial, lateral, caudal and medial sides of knees were analyzed. A significant difference between the groups was observed, with group A temperature being greater than the group B in all four analyzed faces. Comparing the temperatures of the faces in the contralateral limb, in both groups, the statistical analysis revealed no significant difference. In group A it was observed that temperatures in the cranial and lateral sides were similar, but different from the others. In group B, the statistical analysis showed the cranial lateral and caudal faces was similar, but differed from the medial side. The thermographic examination proved to be sensitive in the evaluation of temperature of small dogs' knees; however, the length of the fur influenced the result.

Key words: coat, knees, infrared thermography, imaging diagnosis.

Comparação termográfica entre joelhos saudáveis de cães de pelo longo e pelo curto

RESUMO: O objetivo desse estudo foi verificar a influência do comprimento do pelo na avaliação da temperatura de joelhos de cães saudáveis, por meio do uso da termografia infravermelha. Trata-se de um exame de diagnóstico por imagem, não invasivo, capaz de avaliar a microcirculação da pele. Foram analisados os joelhos de 30 cães saudáveis, com até 11 quilos de peso, triados por meio de exame clínico e exame radiográfico. O grupo A, formado por 13 cães de pelo curto, totalizou 26 joelhos avaliados. O grupo B foi formado por animais de pelo longo, totalizando 17 animais, contando com 29 joelhos avaliados. Foram analisadas as temperaturas médias nas faces cranial, lateral, caudal e medial dos joelhos. Observou-se diferença significativa entre os grupos, a temperatura do grupo A foi maior que a de B nas quatro faces analisadas. Comparando as temperaturas das faces no membro contralateral, nos dois grupos, não foi observado diferença significativa. No grupo A observou-se que as temperaturas nas faces cranial e lateral foram semelhantes, mas diferiram das demais, sendo a medial mais quente e a caudal mais fria. No grupo B a análise estatística mostrou as faces cranial, lateral e caudal semelhantes, entretanto diferiram da face medial, que apresentou a temperatura mais elevada. O exame termográfico mostrou ser sensivel na avaliação da temperatura do joelho de cães de pequeno porte, entretanto o comprimento dos pelos influi no resultado da avaliação.

Palavras-chave: pelagem, temperatura, termografia por infravermelho, diagnóstico por imagem.

\section{INTRODUCTION}

Infrared thermography is a diagnostic imaging technique study, used since the 1960s (BRIOSCHI et al. 2003; WESTERMANN et al. 2013). It has application in various areas of knowledge, in addition to establish use in medicine and veterinary medicine (MEOLA \& CARLOMAGNO, 2004). Infrared thermography is non-invasive, tool, which doesn't emit radiation, does not require anesthesia, can be done remotely and requires no contrast (NG, 2009; MARINO \& LOUGHIN, 2010; WESTERMANN et al. 2013). A thermal camera is a device to focus infrared radiation and to calculate the temperature in each part of the field of view, and the output is expressed as an image colour-coded for temperature, known as a thermogram (INFERNUSO et al. 2010). In addition to thermal imaging, the test quantifies information in real-time and detects very small temperature variations of up to $0.07^{\circ} \mathrm{C}$ in less than $0.03 \mathrm{sec}$ (BRIOSCHI et al. 2007). 
Thermography, as per any diagnostic method, requires minimum standardization before its use (VAINIONPÄ̈̈ et al. 2012). Consideration of the environment, such as temperature, humidity, solar radiation and convective air movement is required. These factors must be recognized and controlled to avoid negative or false positive results (WESTERMANN et al. 2013). Temperature in the exam room should be $21^{\circ} \mathrm{C}$, air conditioners must have sufficient thermal reserve capacity for the room size, which preferably should not have windows, and the flow speed should not exceed $0.2 \mathrm{~m} / \mathrm{s}$. A fluorescently-lit examination room prevents heating and a digital thermo-hygrometer with a sufficiently large display is necessary, allowing data to be viewed from at least $3 \mathrm{~m}$ (BRIOSCHI et al. 2003).

Animal handling should also be considered to avoid artifacts in the examination, such as clipping the hair $60 \mathrm{~min}$ before the air conditioning starts, avoiding touching the sites that will be thermographically imaged, and using latex gloves (INFERNUSO et al. 2010). Some authors (TUNLEY \& HENSON, 2004; INFERNUSO et al. 2010) reported that there is no need to clip the hair for reliable results in skin thermography. The impact of hair length and thickness for thermographic standards and temperature scales remains unknown (INFERNUSO et al. 2010).

Infrared thermography reflects the microcirculatory dynamics of the patient's skin surface in real-time. The skin is a dynamic organ and its temperature is constantly adjusted to balance the external and internal conditions, offsetting the physiological body requests. Sympathetic motor fibers control the cutaneous microcirculation through vasoconstriction or vasodilation, causing smaller or larger skin irrigation. This controlled phenomenon of heat transfer through the skin is defined as thermoregulation and depends on the integrated activities of the autonomic nervous system (BRIOSCHI et al. 2003; GROSSBARD et al. 2014).

Body areas with increased temperature are associated with increased local circulation and metabolism, which can be clinically correlated with inflammation, whereas, a decrease in temperature may be clinically associated with a decrease in tissue perfusion secondary to vascular shunts, infarct or autonomous nervous system changes (GROSSBARD et al. 2014).

In veterinary medicine, infrared thermography has been focused mainly on orthopedic diseases of horses (STRÖMBERG, 1973; TURNER, 2001; HOOGMOED et al. 2000; ÇETINKAYA \&
DEMIRUTKU, 2012). However, there are reports of its use in another species, such as monitoring wild birds (MAcCAFFERTY, 2013), detection of clinical mastitis in cows (HOVINEN et al. 2008), osteosarcoma research in dogs (AMINI et al. 2012), evaluation of the cranial cruciate ligament rupture in dogs (INFERNUSO et al. 2010), and as a diagnostic tool in various species (MAcCAFFERTY, 2007).

In contrast to the vast amount of data on humans and horses (NG, 2009; MARINO \& LOUGHIN, 2010), there is little information about knee thermography in dogs. The use of thermal imaging in small animals is restricted to research and clinical use that is not generally reported (INFERNUSO et al. 2010). However, Marino \& Louchin, (2010), reported their use in clinical routine. Although, thermographic examination use is limited due to the difficulties in validating the method, there is a need to produce information to evaluate its accuracy in a variety of potential situations (RIBEIRO et al. 2009). Although, knee problems is a common orthopedic diseases in small animal clinical practice the thermographic diagnostic is not commonly used to asses those conditions. The aim of this study was to investigate the influence of the length of the fur in the evaluation of knees temperature in healthy dogs, using infrared thermography.

\section{MATERIALS AND METHODS}

The selected dogs were provided by the Federal University of Paraná's Veterinary Hospital (Paraná, Brazil) and private clinics of Joinville (Santa Catarina, Brazil). A combined total of 30 short- and long-haired dogs, up to $11 \mathrm{~kg}$ body weight, of any gender, breed or age were included. Animals with signs of skin, orthopedic or systemic diseases, based on history and clinical examination, were excluded. Both craniocaudal and mediolateral knees were digitally radiographed (Neo-Diagnomax, 500mA, Agfa HealthCare, São Paulo, Brazil) to exclude from the study animals with degenerative articular disease. The patients were then separated into two groups. Group A consisted of 13 short-haired (shorter than $15 \mathrm{~mm}$ ) canines, comprising 26 knees. Group B consisted of 17 long-haired (longer than 15mm) canines, comprising 29 knees.

Dogs were placed in a climatic chamber (average ambient temperature of $21^{\circ} \mathrm{C}$ controlled by a digital thermo-hygrometer), free from the effects of wind and sun for $30 \mathrm{~min}$, Also, to avoid heat from different activities, each dog was maintained individually in a contention box during this period. 
Rectal temperature of all dogs was measured immediately prior to thermographic imaging and care was taken not to touch knees up to $1 \mathrm{~h}$ before and during the exam.

All thermographic images were acquired by the same trained individual. Thermographic images of both knees of each animal were taken at a recommended distance of $40 \mathrm{~cm}$, using a ThermaCAM FLIR E40 (Flir, Boston, USA). The photographed areas were the cranial, medial, lateral and caudal facet of both knees. The evaluated regions were defined as the cranial part of the patella to the caudal portion of the gastrocnemius and the distal third of the femur to the proximal third of the tibia. Squares (20x20 pixels) averaging 400 pixels were analyzed using FLIR Tools ${ }^{\circledR}$.

All results were analyzed using GraphPad Prism v.5 software. Outliers were detected by the Grubbs test, followed by the D'Agostino-Pearson normality test. Differences between the knees temperature of long- and short-haired canines were analyzed by Student's t-test. Temperature differences between the four aspects in each group were analyzed by 2 -way analysis of variance (ANOVA).

\section{RESULTS}

A total of 30 dogs were analyzed, including 13 with short hair, totaling 26 knees (69.2\% female and $30.8 \%$ male) (group A) and 17 with long hair $(58.8 \%$ female and $41.2 \%$ male), totaling 29 knees (group B). The evaluated dogs comprised 18 mongrels, four poodles, one schnauzer, one Scottish terrier, two Lhasa Apso, three Yorkshire and one
Jack Russel. The average bodyweight of group A was $7.02 \mathrm{~kg}$ and $6.87 \mathrm{~kg}$ for group B. Five knees were discarded from the study because of radiographic and clinical changes such as patellar dislocation or history of surgical procedure as arthrotomy that could interfere in the evaluation.

The thermographic test allowed evaluation of the temperature of all healthy knees (Figure 1). The distribution pattern of the temperature was normally distributed. Statistical differences existed between groups $\mathrm{A}$ and $\mathrm{B}$, as well as within the animals from the same group. There were no temperature differences between the evaluated areas in the knees of the same individual. Differences in some aspects temperatures $(\mathrm{p}<0.05)$ were observed between groups. Temperatures of short-haired animals were higher than long-haired dogs (Table 1). In group A, Tukey's test revealed no significant differences between the cranial and lateral sides, while the caudal and medial differed from each other (Figure 2). In group B, the cranial, lateral and caudal aspects did not differ but all were significantly different from the medial facet $(\mathrm{P}<0.05$; Figure 3$)$.

Rectal temperature was evaluated in all animals to avoid that animals with hypothermia or hyperthermia interfered in the result. However, there was no difference in mean rectal temperature between the groups and sex.

\section{DISCUSSION}

It was recommended for this study that the animals rest in plastic transport boxes during acclimatization in the air-conditioned room. Many
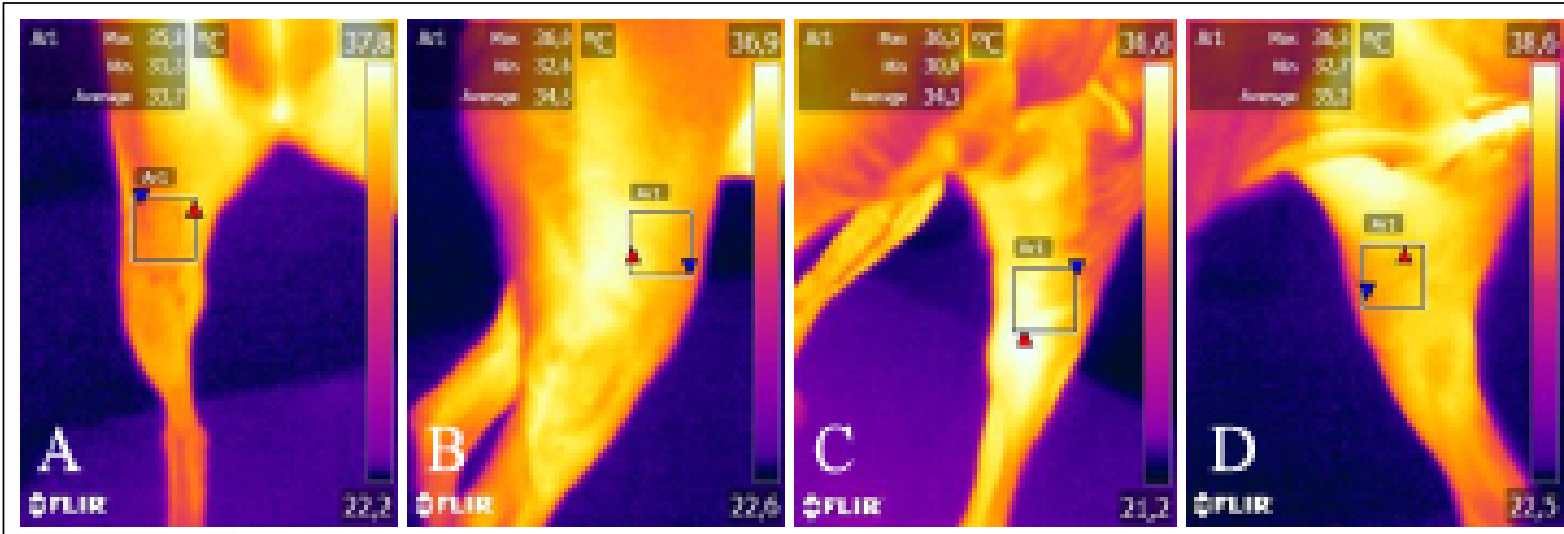

Figure 1 - Thermographic image of a right knee from a dog with short hair (A-cranial; B-lateral; C-caudal and D-medial). 
Table 1 - Comparison of the mean temperature and standard deviation in the cranial, lateral, caudal and medial faces between groups A and $\mathrm{B}$, being ${ }^{*}=\mathrm{P}<0.05$

\begin{tabular}{lcr}
\hline & Group A Short hair & Group B Long hair \\
\hline Cranial & $31.95 \pm 0.4154^{*}$ & $27.99 \pm 0.3807$ \\
Lateral & $32.25 \pm 0.4183^{*}$ & $28.35 \pm 0.3379$ \\
Caudal & $30.14 \pm 0.5767^{*}$ & $28.29 \pm 0.4158$ \\
Medial & $34.68 \pm 0.3169^{*}$ & $32.70 \pm 0.3855$ \\
\hline
\end{tabular}

remained laying on the knee areas evaluated, which were photographed at a later stage. Other studies (INFERNUSO et al. 2010 e VAINIONPÄÄ et al. 2012) have reported that during the acclimatization of animals, it is recommended that they avoid bedtime because they believe that it can interfere with the reading of the images. However, this was not observed in the current study.

Higher temperatures were reported in the knees of short-haired animals compared to those with long hair. This condition could be due to the coat type, where the short hair close to the body allows infrared radiation to pass through the coat via convection and, thus, is captured by the thermographic camera more efficiently (TUNLEY \& HENSON, 2004). Long-haired dogs show minimal temperature loss by convection, so, the coat acts as an insulator, preventing dissipation of infrared radiation from the body. This justifies the findings from the present study and has been recognized and discussed by several authors (EDDY et al. 2001; TUNLEY \& HENSON, 2004; LOUGHIN \& MARINO, 2007; INFERNUSO et al. 2010; VAINIONPÄÄ et al. 2012) and observed in multiple species, such as horses, llamas, and dogs. However, despite this influence being recognized by most authors, there has no comparative study quantifying the findings.

The group A analysis showed that the cranial and lateral aspects were similar but differed from the caudal and medial aspects. The lowest temperature was reported in the caudal facet and despite many of the dogs presenting longer hair in this facet compared to the other aspects, possibly blocking that infrared rays, the images were fully captured by thermography. These findings are similar to those reported by INFERNUSO et al. (2010) where the thermographic

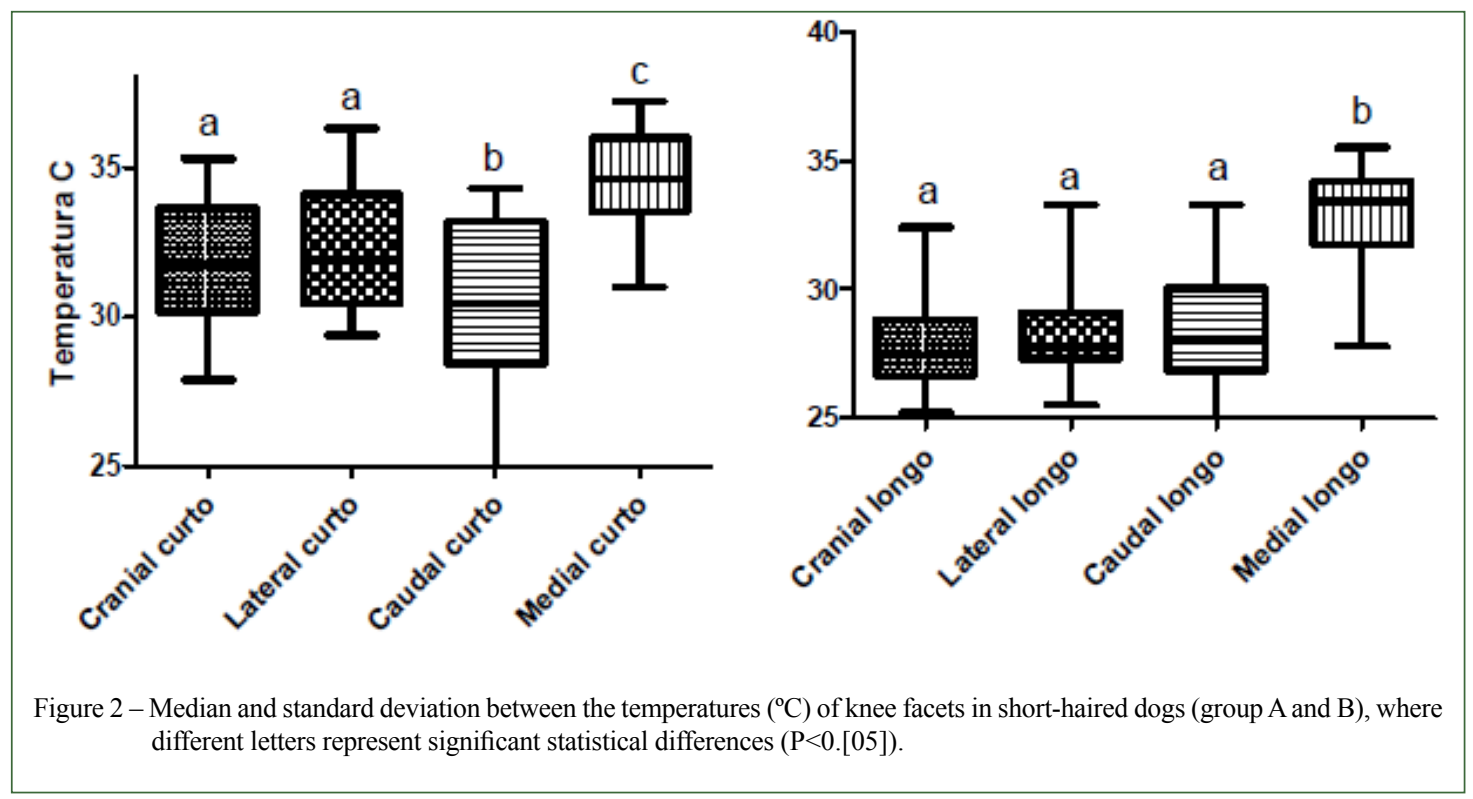

Ciência Rural, v.48, n.12, 2018. 


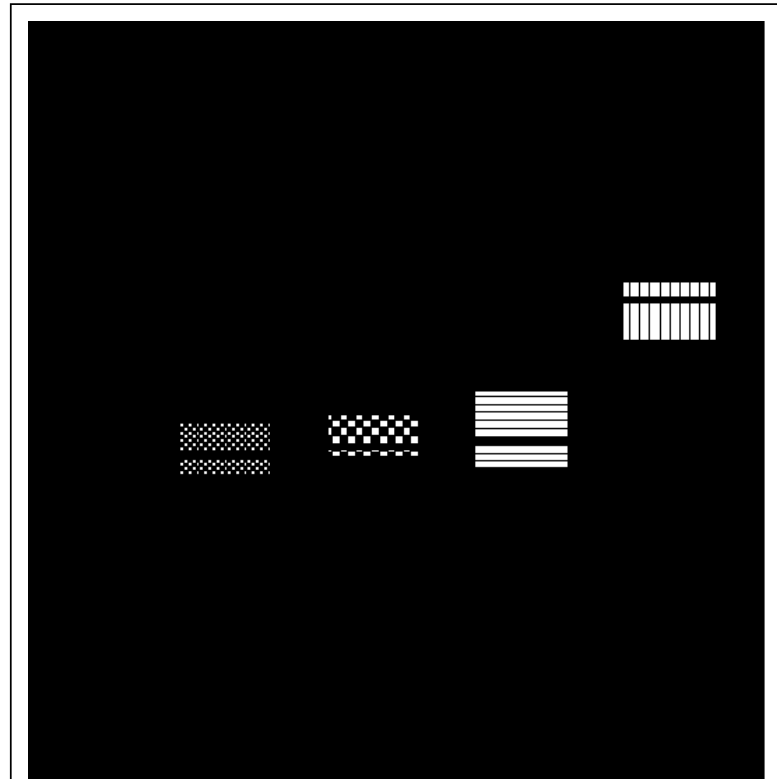

Figura 3 - Median and standard deviation of the temperatures between the different faces of group B, with different letters representing a significant statistical difference, with $\mathrm{P}<0$. [05].

study of large dogs showed that the knees in the control group (healthy) had a warmer thermographic pattern on the medial side, cooler in the caudal and a uniform pattern on the cranial and lateral aspects.

Group B analysis revealed the impact of the coat length on temperature because only the temperature of the medial facet differed from the others. During data collection, it was observed that the coat in the cranial, lateral and caudal regions was relatively dense and long, which blocked much of the infrared radiation emitted from the skin of the dogs. In addition to the thermal insulation, it also caused difficulties in marking areas of interest due to loss of anatomical references. Similarly, a previous study (VAINIONPÄ̈̈ et al. 2012) noted that the hair length and type can compromise the examination due to the loss of anatomic references to define the areas evaluated. Thermographic cameras that capture photographs simultaneously as the thermal image, as done in this study, help to identify anatomical references.

The medial side presented differences from other aspects, showing the highest temperature average. This was because the medial side has the lowest hair density, which allows a more intense dissipation of infrared radiation. Yet, there was a difference between the short- and long-haired animals, which demonstrated a need to standardize the examination according to the coat type or to standardize hair removal to avoid technical artifacts because patient preparation is considered the most important parameter in thermographic examination (BRIOSCHI et al. 2003).

As hair acts an insulator, which sometimes prevents a thermographic evaluation, LOUGHIN \& MARINO (2007) have proposed a novel way to evaluate animals with a full coat, using thermography. This method is based on a software for pattern recognition in thermograms, thus, the temperature does not appreciably interfere with the evaluation. However, this method requires further information because it is not yet possible to reproduce. According to the authors Infernuso et al. (2010), capturing the images also requires a standard because images captured from different angles can confuse the readings by the software. Still, problems occur when analyzing the software images of animals with long and curly hair because the software programs do not recognize the real limits of the areas due to false volume caused by the coat (VAINIONPÄÄ et al. 2012). Indeed, the thermographic images can be easily manipulated in the absence of an extremely 
rigid method, leading to misinterpretation of the automated analysis of these images.

\section{CONCLUSION}

The lack of literature data, no standardization to perform exams and the crescent possibility to use infrared thermography at veterinary patients, promoted interest in evaluating this tool for knee's evaluation in healthy dogs. The thermographic exam showed sensitivity for heat measurement in small dogs; however, the hair coat length sign was significantly in image interpretation. Thus, short hair animals had higher mean temperatures than animals with longer fur, due to minimal convection loss, explained as thermal isolation promoted by his dense hair coat, avoiding dissipation of infrared radiation.

\section{BIOETHICS AND BIOSSECURITY COMMITTEE APPROVAL}

This study was approved by the Ethics Committee for Animal's Use of the Agricultural Sciences Sector of the Universidade Federal do Paraná (UFPR), Brazil as protocol number $017 / 2014$.

\section{DECLARATION OF CONFLICTING INTERESTS}

The authors declare no conflict of interest. The founding sponsors had no role in the design of the study; in the collection, analyses, or interpretation of data; in the writing of the manuscript, and in the decision to publish the results.

\section{AUTHORS' CONTRIBUTIONS}

All authors contributed equally for the conception and writing of the manuscript. All authors critically revised the manuscript and approved of the final version.

\section{REFERENCES}

BRIOSCHI, M. L. et al. Cutaneous thermometry: new concepts. Jornal Vascular Brasileiro 2(2):151-160, 2003.

BRIOSCHI, M. L. et al. Utilização da imagem Infravermelha em reumatologia. Revista Brasileira de Reumatololgia, v. 47, n.1, p. 42-51, 2007.

EDDY,A.L. et al. Review: The role of thermography in the management of equine lameness. The Veterinary Joumal v.162, p.172-181, 2001. Available from: <http://www.ncbi.nlm.nih.gov/ pubmed/11681868?dopt=Abstract $>$. Accessed: Jan. 21, 2014. doi: $10.1053 /$ tvj1.2001.0618.

GROSSBARD, B.P.etal. Medical Infrared Imaging(Thermography) of Type I Thoracolumbar Disk Disease in Chondrodystrophic
Dogs. Veterinary Surgery, v.43, p.1-8, 2014. Available from: $<$ https://www.ncbi.nlm.nih.gov/pubmed/25040309>. Accessed: Jan. 11, 2014. doi: 10.1111/j.1532-950X.2014.12239.x.

HOVINEN, M. et al. Detection of Clinical Mastitis with the Help of a Thermal Camera. Journal of Dairy Science v.91, n.12, 2008. Available from: <https://www.ncbi.nlm.nih.gov/pubmed/19038934>. Accessed: Mar. 13, 2015. doi: 10.3168/jds.2008-1218.

INFERNUSO T. et al. Thermal Imaging of Normal and Cranial Cruciate Ligament-Deficient Stifles in Dogs. Veterinary Surgery v.39, p.410-417, 2010. Available from: <http://onlinelibrary. wiley.com/doi/10.1111/j.1532-950X.2010.00677.x/pdf>. doi: 10.1111/j.1532-950X.2010.00677.x.

LOUGHIN , CA.; MARINO D. J.. Evaluation of thermographic imaging of the limbs of healthy dogs. American Journal of Veterinary Research, v.68, n.10, p.1064-1069, 2007. Available from: $<$ http://www.ncbi.nlm.nih.gov/pubmed/17916011?dopt=Abstract $>$. doi: 10.2460/ajvr.68.10.1064.

MARINO, D. J.; LOUGHIN, CA. Diagnostic Imaging of the Canine Stifle: A Review. Veterinary Surgery v.39, p.284-295, 2010. Available from: <http://onlinelibrary.wiley.com/doi/10.1111/ j.1532-950X.2010.00678.x/pdf $>$. Accessed: Feb. 19, 2015. doi: 10.1111/j.1532-950X.2010.00678.x.

MCCAFFERTY, D. J. The value of infrared thermography for research on mammals: previous applications and future directions. Mammal Review.v.37,n.3,p.207-223,2007.Available from: $<$ http://onlinelibrary. wiley.com/doi/10.1111/j.1365-2907.2007.00111.x/abstract>. Accessed: Jun. 25, 2015. doi: 10.1111/j.1365-2907.2007.00111.x.

MCCAFFERTY, D. J. Review article Applications of thermal imaging in avian science. The International Journal of Avian Science, v.155, p.4-15, 2013. Available from: $<$ http://onlinelibrary. wiley.com/doi/10.1111/ibi.12010/abstract $>$. Accessed: May 22, 2015. doi: 10.1111/ibi.12010.

MEOLA, C.; CARLOMAGNO, GM. Review article recent advances in the use of infrared thermography. Measurement Science and Technology, v. 15, p.R27-R58, 2004. Available from: <http:// iopscience.iop.org/0957-0233/15/9/R01/pdf/0957-0233_15 9 R01. pdf $>$. Accessed: Feb. 23, 2014. doi: 10.1088/0957-0233/15/9/R01.

NG, E.Y.-K. A review of thermography as promising non-invasive detection modality for breast tumor. International Journal of Thermal Sciences v. 48, p.849-859, 2009. Available from: $<$ http:// www.ncbi.nlm.nih.gov/pubmed/17852648?dopt=Abstract $>$. doi: 10.1080/03091900600562040.

RIBEIRO, H. D. W. et al. Real-time infrared thermography as a method of evaluating spleen viability in a model of partial splenectomy in pigs. Revista do Colegio Brasileiro de Cirurgiões, v.36, n.5. p.438-441, 2009. Available from: <http://www.scielo. $\mathrm{br} / \mathrm{scielo}$.php? pid $=\mathrm{S} 0100-69912009000500013 \&$ script $=\mathrm{sci}>$. Accessed: May 08,2015.doi: 10.1590/S0100-69912009000500013.

STRÖMBERG, BERNDT. The Use of Thermography in Equine Orthopedics. Veterinary radiology and ultrasound, v.15, p.94-97, 1974. Available from: <http://onlinelibrary.wiley.com/ doi/10.1111/j.1740-8261.1974.tb00676.x/pdf>. Accessed: May 19, 2015. doi: 10.1111/j.1740-8261.1974.tb00676.x.

TUNLEY, B.V.; HENSON, FMD. Reliability and repeatability of thermographic examination and the normal thermographic image 
of the thoracolumbar region in the horse. Equine Veterinary Journal, v.36, n.4, p.306-312, 2004. Available from: <http://www. ncbi.nlm.nih.gov/pubmed/15163036?dopt=Abstract $>$. Accessed: Jan. 11, 2015. doi: 10.2746/0425164044890652.

TURNER, T.A. et al.. Lameness in the Athletic Horse; Thermographic Assessment of Racing Thoroughbreds. AAEP Proceedings, Vol. 47: 344-346, 2001.
VAINIONPÄÄ, M.,et al., Comparison of Three Thermal Cameras with Canine Hip Area Thermographic Images. J. Vet. Med. Sci. 74(12): 1539-1544, 2012. doi: 10.1292/jvms.12-0180.

WESTERMANN, S. et al. The effect of airflow on thermographically determined temperature of the distal forelimb of the horse. Equine Veterinary Journal, 45, 637-641, 2013. doi: $10.1111 /$ evj.12019. 